\title{
Ontogeny of osmoregulation in the palaemonid shrimp Palaemonetes argentinus (Crustacea: Decapoda)
}

\author{
G. Charmantier ${ }^{1, *}$, K. Anger ${ }^{2}$ \\ 'Laboratoire d'Ecophysiologie des Invertébrés, Université Montpellier II, Place Eugène Bataillon, \\ F-34095, Montpellier cedex 05, France \\ ${ }^{2}$ Biologische Anstalt Helgoland, Meeresstation, D-27498 Helgoland, Germany
}

\begin{abstract}
Osmoregulation was studied in the zoeal stages I and VI, the first decapodid, the first juvenile, and in adults of the palaemonid shrimp Palaemonetes argentinus. The larvae hatch in freshwater creeks or in adjacent brackish coastal lagoons of the warm temperate southwestern coast of the Atlantic Ocean; larval development is possible in low salinities. To cope with these demanding environments, the capacity for osmoregulation is well developed at hatching, increasing only slightly throughout development. All the postembryonic developmental stages hyper-regulated at low salinity ( 1 to $10 \%$, hyper-osmoconformed at $17 \%$, and osmoconformed at higher salinities ( $26 \%$; up to $32 \%$ in adults). The type of osmoregulation did not change during development from larval hatching through the adult phase. The ecological implications and the evolutionary significance of osmoregulation in early lifehistory stages of $P$, argentinus and other aquatic crustaceans are discussed.
\end{abstract}

KEY WORDS: Osmoregulation - Ontogeny $\cdot$ Adaptation $\cdot$ Crustacea $\cdot$ Caridea $\cdot$ Palaemonidae $\cdot$ Larva Palaemonetes

\section{INTRODUCTION}

Salinity is one of the main environmental factors exerting a selection pressure on aquatic organisms. The ability of a species to adapt to environmental salinity and its fluctuations is thus a major adaptive process achieved through different behavioral and/or physiological mechanisms, among which osmoregulation is of major importance for some animal groups, including crustaceans. In adult crustaceans, osmoregulation has been studied in numerous species (reviews in Mantel \& Farmer 1983, Péqueux 1995). More recently, several studies have stressed the adaptive importance of osmoregulation throughout the development of crustaceans, underlining the fact that the ability of each developmental stage to adapt to salinity and its variations is one of the factors permitting the successful

•E-mail: charmantier@univ-montp2.fr establishment of a species in a given habitat (review in Charmantier 1998). But the number of species in which the ontogeny of osmoregulation has been studied is still limited, and it was recently stated that future investigations should be conducted in species submitted to harsh environments (extreme and/or highly variable salinity) during their development (Charmantier 1998, Charmantier et al. 1998).

Among the candidate species in a series of studies in this field is the shrimp Palaemonetes argentinus (Nobili 1901) (Decapoda: Caridea: Palaemonidae). This species is found in an area covering the north and center of Argentina, Uruguay and southern Brazil (Spivak 1997). Although it is generally considered a freshwater species, it has also been found in brackish coastal lagoons extending along the coast of the warm temperate southwestern Atlantic Ocean (review in Spivak 1997), particularly in Mar Chiquita lagoon, Argentina, in which ample variations of salinity have been reported (Anger et al. 1994). 
The larval development of Palaemonetes argentinus was described from laboratory-reared shrimp (MenúMarque 1973). It comprises a variable number of zoeal and decapodid stages. Under natural conditions, the biological cycle of $P$. argentinus can be accomplished in either freshwater or brackish water (review in Spivak 1997). The life history of a population living in the brackish lagoon of Mar Chiquita, Argentina, and in adjacent freshwater creeks has recently been described by Spivak (1997). All developmental stages of this species have been found together in this lagoon, indicating larval development within the parental habitat (Anger et al. 1994).

Since coastal lagoons like Mar Chiquita are characterized by highly variable salinity regimes, fluctuating between freshwater and seawater (Anger et al. 1994), this species is exposed to a wide salinity range throughout its life cycle. The objectives of the present study were thus (1) to determine the ability of selected postembryonic stages of development to osmoregulate, and (2) to relate their osmoregulatory capabilities with available data on the developmental ecology of this species.

\section{MATERIALS AND METHODS}

Specimens: origin and culture. Juvenile shrimp Palaemonetes argentinus were collected near the mouth of a freshwater creek, Arroyo Sotelo, flowing into the Mar Chiquita lagoon, Argentina (for more details of the habitat see Spivak 1997), and transported live in water from the capture site ( $1 \%$ salinity) to the marine biological station Helgoland, Germany. They were reared to adulthood at $1 \%, 24^{\circ} \mathrm{C}$ and a $12 \mathrm{~h}$ light: $12 \mathrm{~h}$ dark cycle, with Artemia sp. nauplii or isopods (Idotea spp.; in late juvenile stages only) given as food.

Since preliminary experiments (Anger unpubl.) had shown that larval development requires brackish water, larvae were reared from hatching through metamorphosis at $5 \%$, using aerated beakers $\left(1 l_{i}\right.$ other conditions as in juvenile rearing). Water and food (freshly hatched Artemia sp, nauplii) were changed daily. The developmental stages used in experiments were the first and the last zoeal stage (zoea I, VI), the first decapodid (postembryonic instar VII), the first juvenile stage (reached after a total number of 6 zoeal and 2 to 5 decapodid stages; for terminology of larval stages see Williamson 1982) and adults (males and females, total body length ranging from 2.4 to $3.6 \mathrm{~cm}$ ).

The duration of successive larval stages was 2 to $3 \mathrm{~d}$. Stages within each molting cycle (Drach 1939) were determined according to the time elapsed since the last preceding ecdysis, distinguishing between the initial postmolt stages ( $A$ and $B$ ), intermolt $(C)$ in the middle, and premolt (D) near the end of the molt cycle. Hemolymph samples were collected exclusively from stage $\mathrm{C}$ individuals. In zoeal, decapodid and first juvenile stages, this was defined as the middle of the instar period. The validity of this staging method was occasionally confirmed through microscopical observations taking the telson or uropods as reference body parts (Drach 1939, Drach \& Tchernigovtzeff 1967, Anger 1983). In adult shrimps, stage $C$ individuals were selected after microscopical observation of the uropods (Drach \& Tchernigovtzeff 1967).

Preparation of media. Experimental media were prepared and stored in $5 \mathrm{I}$ plastic containers for the entire duration of the experiments. Dilute media were prepared by adding desalinated freshwater to natural North Sea water. All experiments were conducted at a constant temperature of $24^{\circ} \mathrm{C}$. Salinities were expressed as osmotic pressure (in mOsm $\mathrm{kg}^{-1}$ ) and as salt content of the medium (in \%); a value of $3.4 \%$ is equivalent to $100 \mathrm{mOsm} \mathrm{kg}^{-1}\left(29.41 \mathrm{mosm} \mathrm{kg}^{-1}\right.$ per $1 \%$ ). The osmotic pressure of the media was measured with a microosmometer Model $3 \mathrm{MO}$ (Advanced Instruments, Needham Heights, MA, USA) requiring $20 \mu \mathrm{l} \mathrm{sample}{ }^{-1}$. Media with the following osmolalities (mOsm kg-1) and corresponding salinities $(\%)$ were prepared and used for all stages: $31 \mathrm{mOsm} \mathrm{kg} \mathrm{k}^{-1}(1.1 \%), 77$ (2.6), 156 (5.3), $302(10.3), 500(17.0)$, and 755 (25.7). Adult shrimp were also exposed to seawater, $947 \mathrm{mOsm} \mathrm{kg}^{-1}(32.2 \%)$.

Osmoregulation. Zoeal and decapodid stages were exposed to the experimental media in covered petri dishes. In decapodids, a particular escape behavior (jumping) had to be prevented by placing additionally a sheet of nylon gauze (200 $\mu \mathrm{m}$ mesh size) on the water surface. Later stages (juvenile I, adults) were placed in glass vials $(250 \mathrm{ml}$ and $1 \mathrm{l}$ capacity, respectively $)$. These were covered with a convex glass lid, the bottom of which touched the surface of the media to prevent jumping; at the margins of the vials, a ring of air allowed for gas exchange.

Hemolymph osmolality was determined for each stage after a period of osmotic stabilization in each medium. Based upon results from previous studies on different species (Charmantier 1998), larvae and first juveniles were kept for $24 \mathrm{~h}$ in each medium before sampling; the acclimation time in adults was $48 \mathrm{~h}$. Larvae and juveniles were superficially dried on filter paper, then quickly immersed in mineral oil to avoid evaporation and desiccation. The remaining adherent water was aspirated through a glass micropipette. Another micropipette was then inserted in the heart to sample hemolymph. In adult shrimp, hemolymph was collected from a cut fourth or fifth pereiopod, after carefully drying it with filter paper.

For all developmental stages, hemolymph osmolality was measured with reference to the medium osmolality on a Kalber-Clifton nanoliter osmometer (Clifton 
Technical Physics, Hartford, CT, USA) requiring about $30 \mathrm{nl}$. The results were expressed either as hemolymph osmolality or as osmoregulatory capacity (OC), defined as the difference between the osmolalities of hemolymph and the medium. Analysis of variance (ANOVA) and Student's $t$-tests were used for multiple and pairwise statistical comparisons of mean values, respectively, after appropriate checks for normal distribution and equality of variance (Sokal \& Rohlf 1995).

\section{RESULTS}

Osmoregulation by the developmental stages was evaluated over a wide range of salinities. The results are given as variations in the hemolymph osmolality and as $O C$ in relation to the osmolality and salinity of the medium (Figs. $1 \& 2$ ).

The pattern of osmoregulation did not change during development. All tested stages hyper-regulated in the dilute media $(<17 \%$ ), hyper-osmoconformed at $17.0 \%$ and isoconformed at $25.7 \%$; the adult shrimp isoconformed also in seawater $(32.2 \%$ ). Thus, the pattern of hyper-iso-osmoregulation was present already in the zoea I, and it persisted in the decapodid, juvenile and adult stages of the life cycle (Fig. 1).

The ability to hyper-osmoregulate at low salinity tended to increase slightly during early development, as demonstrated by variations in hemolymph osmolality (Fig. 1) or in OC (Fig. 2). At very low salinities (1.1 and $2.6 \%$ ), the hyper-OC did not change between zoeal stages I and VI, then it increased slightly in the deca-

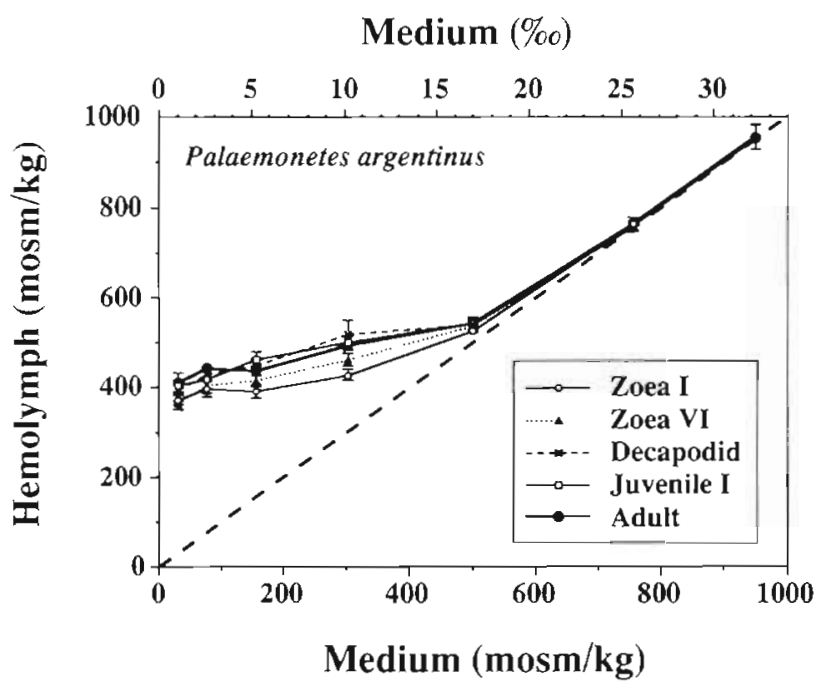

Fig. 1. Palaemonetes argentinus. Variations of the hemolymph osmalality in different stages of postembryonic development in relation to the osmolality and salinity of the medium at $24^{\circ} \mathrm{C}_{i}$ error bars: $\bar{x} \pm \mathrm{SD} ; \mathrm{n}=4$ to 10 (zoeae I and VI) and 7 to 12 (later stages) individuals; dashed line: isoconcentration

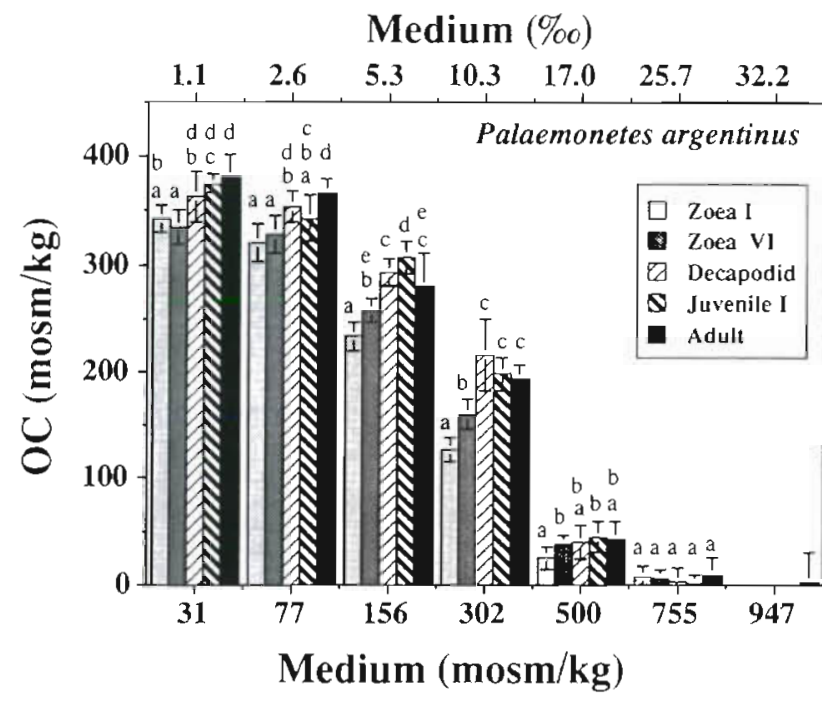

Fig. 2. Palaemonetes argentinus. Variations of the osmoregulatory capacity $(O C)$ in different stages of postembryonic development in relation to the osmolality and salinity of the medium at $24^{\circ} \mathrm{C}_{\text {; }}$ error bars: $\vec{X} \pm \mathrm{SD}_{;} \mathrm{n}=4$ to 10 (zoeae I and VI) and 7 to 12 (later stages) individuals; different letters above error bars indicate significant differences between stages $(\mathrm{p}<0.05)$

podid stage. No important variation in OC was noted in later developmental stages, i.e. in the juvenile I and adults. At moderately low salinities (5.3 and $10.3 \%$ ), the hyper-OC increased significantly from zoea I to zoea VI and the decapodid stage. In subsequent stages, it remained almost unchanged, with a slight tendency to decrease in adults at 5.3\%. At 17.0 and $25.7 \%$, there was little ontogenetic variation in OC. At $25.7 \%$, all stages osmoconformed, as did the adults at $32.2 \%$.

Since $32.2 \%$ is an unusually high salinity for Palaemonetes argentinus under natural conditions, a group of 13 adult shrimps was exposed for several days to this medium. The water was aerated and changed regularly, and the shrimps were fed. The median lethal time (LT 50) for 7 of them was $11 \mathrm{~d}$. No mortality was noted in a control group of shrimp maintained for the same time at $1 \%$.

\section{DISCUSSION}

Among the decapod species which have been studied for their osmoregulation, most marine and brackish-water caridean shrimps hyper-hypo-osmoregulate as adults. In particular, they display an efficient hyporegulation in seawater (925 to $1000 \mathrm{mOsm} \mathrm{kg}$, ca 31.5 to $34.0 \%$; review in Mantel \& Farmer 1983). In the genus Palaemonetes, reported hypo-osmoregulatory capacities in seawater were $-320 \mathrm{mOsm} \mathrm{kg} \mathrm{k}^{-1}$ in $P$. varians (Potts \& Parry 1964), $-380 \mathrm{mOsm} \mathrm{kg}^{-1}$ in $P$. inter- 
medius (Dobkin \& Manning 1964), and -275 mOsm $\mathrm{kg}^{-1}$ in $P$. pugio (Roesijadi et al. 1976). This is in contrast to adult $P$, argentinus, which hyper-regulate at low salinities and hyper-osmoconform or isoregulate at higher salinites up to $32.2 \%$.

Many freshwater caridean shrimps are actually euryhaline and can thus adapt to relatively high salinities in the range of 25 to $33 \%$. Some of these have retained a capacity to hypo-regulate in seawater, e.g. Macrobrachium rosenbergii (Sandifer et al. 1975) and $M$. petersi (Read 1984), while others osmoconform at $700 \mathrm{mOsm} \mathrm{kg} \mathrm{kg}^{-1}$ (ca 23.8\%) and above, e.g. Palaemonetes paludosus (Dobkin \& Manning 1964). P. argentinus clearly belongs to this latter group. It is a strict osmoconformer in salinities of about 20 to $32.2 \%$. Survival under these conditions is limited to a few days, and, in brackish-water habitats such as Mar Chiquita lagoon, the shrimps tend to avoid high-salinity areas (Anger et al. 1994).

At the other end of the salinity spectrum, Palaemonetes argentinus is well adapted to low and very low salinities through efficient hyper-osmoregulation. This supports the general view of this shrimp as a freshwater species (Spivak 1997). At $31 \mathrm{mOsm} \mathrm{kg}^{-1}$ (1.1\%; i.e. at conditions close to freshwater), adult individuals maintain hemolymph osmolality at about $410 \mathrm{mOsm}$ $\mathrm{kg}^{-1}$. This average value is within the 350 to 550 (most frequently 400 to 500 ) mOsm $\mathrm{kg}^{-1}$ range reported for hemolymph osmolality in freshwater decapods, including caridean shrimps (e.g. $P$. antennarius: 400 mOsm $\mathrm{kg}^{-1}$, Parry 1957; P. paludosus: 470 mOsm kg-1, Dobkin \& Manning 1964), crayfishes, and some potamid crabs (review in Mantel \& Farmer 1983). The strong ability of $P$. argentinus to hyper-regulate in media close to freshwater most probably depends, at least in part, on active ion pumping by specialized osmoregulatory tissues in the branchial chamber. Their location would be worth studying. In addition, it has been demonstrated that some freshwater caridean shrimps can, as do crayfishes, produce a hypo-osmotic urine to prevent ion loss (reviews in Mantel \& Farmer 1983, Péqueux 1995) Very few palaemonid shrimps have been studied with respect to urine concentration, and since several of them, including $P$. argentinus, are known to penetrate into freshwater, the contribution of the excretory organs to hyper-osmotic regulation in this species would be another interesting field of research

The pattern of osmoregulation does not change during the postembryonic development of Palaemonetes argentinus. The zoea I and VI and, most probably, all other zoeal stages are hyper-isoregulators, with a slight ontogenetic increase in the ability to hyperregulate at 5 and $10 \%$. In decapodids, which are morphologically and physiologically transitional between zoeae and juveniles, the ability to hyper-regulate at low salinities increases, but the pattern of hyperisoregulation remains the same. This also applies, without important changes in regulation efficiency, to the first juvenile and the adult stages.

This ontogenetic pattern in the capability for osmoregulation can be assigned to 1 of 3 principal types described by Charmantier (1998). Palaemonetes argentinus belongs to the second category, in which the adult type of efficient osmoregulation is established as early as in the first postembryonic stage. Among the other crustaceans belonging to this category there are several branchiopod cladocerans (Aladin \& Potts 1995), Artemia salina (Conte 1984), the amphipod Gammarus duebeni (Morritt \& Spicer 1995), the isopods Cyathura polita (Kelley \& Burbanck 1972) and Sphaeroma serratum (Charmantier \& Charmantier-Daures 1994), and, among the decapods, the palaemonid shrimp Macrobrachium petersi (Read 1984) and the crayfish Astacus leptodactylus (Charmantier-Daures \& Charmantier 1997). A feature common to these species is that they live in osmotically harsh habitats. Since they are exposed to high osmotic stress upon hatching, these species have adapted through the appearance of efficient osmoregulatory processes in the first (and subsequent) postembryonic stages. In freshwater species (including $P$. argentinus) this translates into high values of hemolymph osmolality at very low salinity. As the ability to osmoregulate depends on specialized tissues and organs (review in Charmantier 1998) their structural and functional ontogeny will be an interesting field for future research throughout the development of $P$. argentinus. Since, in this species, the pattern of osmoregulation is basically the same from early zoeae to adults, additionally the question arises whether the same or different osmoregulatory tissues and organs are involved throughout ontogeny.

There is mounting evidence that the ability of young developmental stages to osmoregulate is an important adaptive process. The possession of high osmoregulatory capabilities at hatching is one of the adaptive factors permitting the development of Palaemonetes argentinus in freshwater or in coastal areas such as Mar Chiquita lagoon. This shallow lagoon covering $46 \mathrm{~km}^{2}$ is constantly fed with freshwater (salinity ca $1 \%$ ), and seawater (ca 33.5\%) can intermittently enter and leave according to different factors associated with the topography of the mouth of the lagoon, the lunar cycle, tidal amplitude, and the direction and strength of winds. The resulting salinity in the habitat of $P$. argentinus can be low ( 1 to $5 \%$ ) for extended periods of several days, or it can vary between 1 and $30 \%$ within a few hours (Anger et al. 1994). Given the important osmoregulatory abilities of this species at all postembryonic stages in media ranging from freshwater to seawater, the palaemonid shrimp $P$. argenti- 
nus has been able to invade freshwater habitats, while retaining the ability of adapting to brackish habitats with variable salinity.

Similar ecophysiological correlations have been established in species living in habitats with demanding salinity features, for instance under variable conditions in shallow coastal waters or lagoons (Sphaeroma serratum: Charmantier \& Charmantier-Daures 1994; Gammarus duebeni: Morritt \& Spicer 1995), temporary rainfall puddles (Uca subcylindrica: Rabalais \& Cameron 1985) and supratidal rockpools (Armases miersii: Charmantier et al. 1998), in extremely high salinities (Artemia salina: Conte 1984), in freshwater (Astacus leptodactylus: Charmantier-Daures \& Charmantier 1997), and in species that accomplish ontogenetic migrations between habitats with different salinity regimes (Macrobrachium petersi: Read 1984; Penaeus japonicus: Charmantier et al. 1988). An improved understanding of the ecological implications and of the adaptive and evolutionary significance of the ontogeny of osmoregulation should come from further studies conducted on other species living in diverse habitats, and from investigations on the physiological basis of the ontogeny of osmoregulation.

Acknowledgements. G.C. thanks Prof. Dr F. Buchholz, Head of the Helgoland Section of the Stiftung Alfred-WegenerInstitut, Biologische Anstalt Helgoland, for receiving him at the marine biological station. The authors thank Dr M. Charmantier-Daures for help and critical reading of the manuscript, K. Riesebeck, K. Paschke, K. Pfaff and G. and L. Gimenez for occasional technical help, U. Alexander and M. A. Garcia for secretarial assistance. This is a contribution to a cooperative research programme, MAR- 8 , between the Universidad Nacional de Mar del Plata (Argentina) and the Biologische Anstalt Helgoland (Germany), funded by the Federal Ministry of Science and Technology (Bonn) and SECYT (Buenos Aires). A grant from the French Ministère des Affaires Etrangères was awarded to G.C.

\section{LITERATURE CITED}

Aladin NV, Potts WTW (1995) Osmoregulatory capacity of the Cladocera. J Comp Physiol B 164:671-683

Anger K (1983) Moult cycle and morphogenesis in Hyas araneus larvae (Decapoda, Majidae) reared in the laboratory. Helgol Meeresunters 36:285-302

Anger K, Spivak E, Bas C, Ismael D, Luppi T (1994) Hatching rhythms and dispersion of decapod crustacean larvae in a brackish coastal lagoon in Argentina. Helgol Meeresunters 48:445-466

Charmantier G (1998) Ontogeny of osmoregulation in crustaceans: a review. Invertebr Reprod Dev 33:177-190

Charmantier G, Charmantier-Daures M (1994) Ontogeny of osmoregulation and salinity tolerance in the isopod crustacean Sphaeroma serratum. Mar Ecol Prog Ser 114: $93-102$

Charmantier G, Charmantier-Daures M, Bouaricha N, Thuet P, Aiken DE, Trilles JP (1988) Ontogeny of osmoregulation and salinity tolerance in two decapod crustaceans $\mathrm{Ho}$ marus americanus and Penaeus japonicus. Biol Bull
(Woods Hole) 175:102-110

Charmantier G, Charmantier-Daures M, Anger K (1998) Ontogeny of osmoregulation in the grapsid crab Armases miersii (Crustacea, Decapoda). Mar Ecol Prog Ser 164 285-292

Charmantier-Daures M, Charmantier G (1997) Osmoregulatory ability of early juvenile crayfish Astacus leptodactylus. Am Zool 37:140 (abstract)

Conte FP (1984) Structure and function of the crustacean larval salt gland. Int Rev Cytol 91:45-106

Dobkin S, Manning RS (1964) Osmoregulation in two species of Palaemonetes (Crustacea: Decapoda) from Florida. Bull Mar Sci Gulf Caribb 14:149-157

Drach P (1939) Mue et cycle d'intermue chez les Crustacés Décapodes. Ann Inst Oceanogr Monaco 19:103-391

Drach P, Tchernigovtzeff C (1967) Sur la méthode de détermination des stades d'intermue et son application générale aux Crustacés. Vie Milieu 18A:595-609

Kelley BJ Jr, Burbanck WD (1972) Osmoregulation in juvenile and adult Cyathura polita (Stimpson) subjected to salinity changes and ionizing gamma irradiation (Isopoda, Anthuridea). Chesapeake Sci 13:201-205

Mantel LH, Farmer LL (1983) Osmotic and ionic regulation. In: Mantel LH (ed) The biology of Crustacea, Vol 5. Internal anatomy and physiological regulation. Academic Press, New York, p 53-161

Menú-Marque SA (1973) Desarrollo larval de Palaemonetes argentinus (Nobili, 1901) en el laboratorio (Crustacea, Caridea, Palaemonidae). Physis (B Aires) 32:149-169

Morritt D, Spicer JI (1995) Changes in the pattern of osmoregulation in the brackish water amphipod Gammarus duebeni Lilljeborg (Crustacea) during embryonic development. J Exp Zool 273:271-281

Nobili G (1901) Decapodi racolti dal Dr Filippo Silvestri nell' America meridionale. Boll Mus Zool Univ Torino 16:1-15

Parry G (1957) Osmoregulation in some fresh water prawns J Exp Biol 34:417-423

Péqueux A (1995) Osmotic regulation in crustaceans. J Crustac Biol 15:1-60

Potts WTW, Parry G (1964) Sodium and chloride balance in the prawn, Palaemonetes varians. J Exp Biol 41:591-601

Rabalais NN, Cameron JN (1985) The effects of factors important in semi-arid environments on the early development of Uca subcylindrica. Biol Bull (Woods Hole) 168:147-160

Read GHL (1984) Intraspecific variation in the osmoregulatory capacity of larval, post-larval, juvenile and adult Macrobrachium petersi (Hilgendorf). Comp Biochem Physiol 78A:501-506

Roesijadi G, Anderson J, Petrocelli S, Giam C (1976) Osmoregulation of the grass shrimp Palaemonetes pugio exposed to polychlorinated biphenyls (PCBs). I. Effects on chloride and osmotic concentrations and chloride and water-exchange kinetics. Mar Biol 38:343-355

Sandifer PA, Hopkins JS, Smith T (1975) Observations on salinity tolerance and osmoregulation in laboratoryreared Macrobrachium rosenbergii post-larvae. Aquaculture 6:103-114

Sokal RR, Rohlf FJ (1995) Biometry. The principles and practice of statistics in biological research. WH Freeman and Co, San Francisco

Spivak ED (1997) Life history of a brackish-water population of Palaemonetes argentinus (Decapoda: Caridea) in Argentina. Ann Limnol 33:179-190

Williamson DI (1982) Larval morphology and diversity. In Abele LG (ed) The biology of Crustacea, Vol 2. Embryology, morphology and genetics. Academic Press, New York, p 43-110 